\title{
The Use of Tanniferous Plants to Control Infestations of Haemonchus contortus Parasites in Meat Goats ${ }^{1}$
}

\author{
Tyrell Kahan, Sally Williams, Ray Mobley, Ikechukwu Ezenwa, and Eric Peterson ${ }^{2}$
}

The use of tanniferous plants to control internal parasites in meat goats is a promising alternative to reducing or eliminating the use of synthetic drugs.

\section{Summary}

The economic benefits of developing a comprehensive natural alternative anthelmintic management program that includes the use of tanniferous plants would have significant health and economic impact on the meat goat industry.

Tanniferous plants also have significant crude protein content that provides an inexpensive protein source.

\section{Statement of Problem}

The United States meat goat industry is increasing significantly. Goat populations worldwide accounted for 743,374,300 head, with 440,291,400 produced by developing countries (Food and Agriculture Organization, 2003). The state of Florida produced 65,000 meat and "other goats" at the end of 2006. There was an increase of $8.33 \%$ in the Florida meat and other goat production between 2005 and 2006 (USDA NASS, 2007). The majority of goat meat sold in Florida is imported from foreign sources such as Australia. However, this trend is in the process of changing as the interest in goat meat in Florida and surrounding Southeast areas increases.

A major impediment to the growth of the goat industry, both in Florida and on a world-wide scale, is loss caused by gastrointestinal parasites.

Gastrointestinal parasitism is a major concern in the small ruminant industry. Infestation of goat herds results in major health issues which lead to poor animal performance and economic loss. Currently, chemical anthelmintics are used to control gastrointestinal parasites. However, the increased resistance of parasites to anthelmintics will eventually result in a major crisis. In addition, consumers are demanding the use of natural alternatives instead of synthetic drugs in the production of animals for food. Although numerous solutions are beginning to emerge, the use of tanniferous plants to control internal parasites appears to be a promising procedure (Paolini et al., 2004, Waller, 2004).

1. This document is AN199, one of a series of the Department of Animal Sciences, Florida Cooperative Extension Service, Institute of Food and Agricultural Sciences, University of Florida. Published March 2008. Visit the EDIS Web Site at http://edis.ifas.ufl.edu.

2. Tyrell Kahan, Former Honors Animal Science Undergraduate Student, Department of Animal Sciences; Sally Williams, Associate Professor, Department of Animal Sciences; Florida Cooperative Extension Service, institute of Food and Agricultural Sciences, University of Florida, Gainesville, FL 32611; Ray Mobley, Associate Professor, CESTA, Florida Agricultural and Mechanical University, Tallahassee, FL; Ikechukwu Ezenwa, former Assistant Professor, Southwest Florida Research and Education Center; Immokalee, FL; Eric Peterson, DVM, CESTA, Florida Agricultural and Mechanical University, Tallahassee, FL.

The Institute of Food and Agricultural Sciences (IFAS) is an Equal Opportunity Institution authorized to provide research, educational information and other services only to individuals and institutions that function with non-discrimination with respect to race, creed, color, religion, age, disability, sex, sexual orientation, marital status, national origin, political opinions or affiliations. U.S. Department of Agriculture, Cooperative Extension Service, University of Florida, IFAS, Florida A. \& M. University Cooperative Extension Program, and Boards of County Commissioners Cooperating. Larry Arrington, Dean 


\section{Current Anthelmintics Used to Treat Goats}

The four major classes of anthelmintics include benzimidazoles, avermectins, imidothiazoles and pyrimidines. In Florida, cydectin, a member of the avermectin family, is the most widely-used anthelmintic because of the development of parasite resistance to many of the other classes of anthelmintics (Gaskin, 2006). A typical parasite treatment program includes:

1. Medicate every animal every four weeks during periods of high rainfall and every six weeks during low rainfall.

2. Treat all kids before being weaned.

3. Treat all pregnant animals a month before and after they give birth.

4. Treat all other groups of animals once a month when they are grazed on pasture (Chandrawathani et al., 2004).

This frequent and haphazard drug administration procedure has contributed to the rise in resistance of parasites to anthelmintics and the development of serious side effects in the animals. This procedure is not economically feasible for producers because they cannot afford the expensive drugs. Many of the anthelmintic drugs do not have approved withdrawal times for milk and, therefore, cannot be used during lactation (Akhtar and Ahmad, 1992; Luginbuhl, 2002).

\section{Tanniferous Plants: A Natural Alternative}

Haemonchus contortus, also known as the "barber pole worm," is the most pathogenic of the intestinal worms in goats. Tanniferous forages that have been evaluated to control $H$. contortus include legume forages such as sainfoin, sericea lespedeza, and quebracho; and woody forages such as oak trees, jackfruit, leucena and mimosa (Paolini et al., 2005a, 2005b; Semenye, 1990).

Researchers (Min and Hart, 2003; Hoste et al., 2005 and Paolini et al., 2005a) have determined that the consumption of sainfoin, a tanniferous forage, does not appear to be unfavorable to milk yield and quality in dairy goats. Also, forages with moderate levels of condensed tannins (CT - Condensed tannins are tannins that are not metabolized to form compounds that are toxic to ruminants) appear to have some positive effects on milk production in dairy cattle and dairy ewe. When ruminants are fed high concentrations of tannins, however, the negative effects on protein digestibility could negatively impact milk production (Min and Hart, 2003). Chemical composition, molecular size, and concentration of CT are all important factors in relation to the effect of CT on gastrointestinal worms (Min and Hart, 2003). These factors vary by the species of the plant.

In addition to the antinutritional effects that can result from high tannin consumption, some plants with high tannin content also cause toxicity due to secondary chemicals that the plants contain. For example, Leucena contains an amino acid, mimosine, which can cause deleterious effects when consumed in high quantities. Some signs of clinical toxicity include excessive salivation, alopecia (hair loss), loss of appetite, uncoordinated gait and the enlargement of the thyroid gland. Some goats appear to be immune to toxicity by this chemical. It is said to be due to the presence of microbes in their rumen that can break down the toxic chemical. These microbes appear to be in goats that come from an area where Leucena is indigenous (Semenye, 1990).

Quebracho is an extract from the bark of the tropical tree Schinopsis sp. that is commercially available in France. A decrease in the fecal egg counts of $H$. contortus has been observed in goats and sheep fed quebracho although there was no effect on the number of mature worms (Paolini et al., 2004).

Sainfoin (Onobrychis viciifolia) is legume forage that can be fed fresh or in a hay form. It has a high concentration of CT with 50 to $80 \mathrm{~g}$ of CT/ $\mathrm{kg}$ of dry matter. Sainfoin hay appears to be highly palatable to goats. In fact, when goats are fed sainfoin hay, a high consumption rate is observed. It has been shown to have potential in controlling parasite infection in goats by decreasing worm egg excretion and increasing host resilience. (Paolini et al., 2004, 2005a, 2005b). 
Leucena (Leucena leucocephala and Leucena diversifolia) is a leguminous tree found in the tropics that has high protein content (leaves contain 25-30\% crude protein). It has been shown to have the potential to be a high quality forage for small ruminants because it grows fast, roots deeply, tolerates diverse moisture conditions, and contains a variety of minerals including phosphorus, potassium, magnesium, calcium, trace minerals, and vitamin A. The level of intake should be regulated to prevent toxicity because of the presence of mimosine (Semenye, 1990; Adejumo and Ademosun, 1991).

Sericea lespedeza or Chinese bush clover (Lespedeza cuneata), fed as fresh forage or hay, reduces faecal egg counts and inhibits the development of the larvae of $H$. contortus (Min et al., 2004; Lange et al., 2006; and Shaik et al., 2006) suggested that Sericea lespedeza may have greater potential in treating animals infected by $H$. contortus than quebracho extract. This is based on a lethal effect of Sericea lespedeza that was observed in established worm populations in sheep. This plant is insect- and disease-resistant, thrives in poor conditions and has a high forage yielding capacity. Other plants that have exhibited anti-parasitic effects against $H$. contortus larvae include mimosa, papaya, cassava hay, goava leaf, Mimisa isp. and Flemingia macrophylla (Nyguyen et al., 2005).

\section{Goats' Tolerance to Tannins}

The natural propensity of goats to browse has resulted in the development of a tolerance to defensive chemicals such as tannins which are inherent in tanniferous forages. Some possible explanations for the tolerance of goats to tannins are the ability of the microbes in the goat's rumen to break down tannins, and the existence of secretions in the saliva that bind tannins (Min and Hart, 2003). Scoggings et al. (2004) indicated that goats have a tolerance to tannins because they have the ability to elevate their intake rates of plants with high tannin levels for short periods of time and limit long-term intake of the plants. A negative aspect of the use of woody plants in a commercial production system is that they usually are not as resilient to being eaten as grasses. Therefore, the plants must be incorporated into the pasture in strategic locations in order to maximize forage consumption throughout the pasture.

\section{Anthelmintic Effects of Tanniferous Plants on $\boldsymbol{H}$. contortus Parasites}

Consumption of tannins has resulted in positive effects on the hosts of $H$. contortus by decreasing the fertility of the female worm, which results in decreased shedding of eggs by the host, and reduction in pasture contamination. When the female worm fertility was measured by counting the number of eggs in utero, the number of eggs was significantly less than with worms not treated with tannins. The decrease in egg excretion seen with the consumption of tannins could reduce the contamination of pastures (Paolini et al., 2005b). The parasite is ubiquitous in pastures and tends to thrive especially well in tropical and subtropical environments such as Florida (Paolini et al., 2004; Waller, 2004). H. contortus is haematophagous, which means that it feeds on the blood of its host. It lives in the abomasum, where it attaches with its mouth to feed, mature, and eventually reproduce. $H$. contortus is a very fertile species. The female lays about 5000 eggs per day, which exit the animal (goat) through the feces. The eggs hatch, and the larvae inhabit the water that develops on blades of grass from dew or rain. When the host (goat) ingests the larvae while grazing on the contaminated pastures, the cycle continues. It takes about 3 weeks to complete the life cycle of the worm, but if the worm enters the survival stage of arrested development, the worm could survive for months. Arrested development involves the larvae remaining in the abomasums of the animal without maturing until months afterwards. This allows the worm to survive the winter months when the egg and larvae do not thrive well on the ground. The survivability of the free-living stage of $H$. contortus is short. Most infective larvae vanish from the pasture within 4-6 weeks in a wet tropical environment (Waller, 2004).

\section{Clinical Signs of Internal Parasite Infestation}

The major clinical signs of a heavy internal parasite infestation are anemia, bottle-jaw and wasting away, or a decrease in weight gain 
performance. Anemia results from parasites sucking the blood of the host. It can be observed in the mucous membranes, particularly those around the eyes and the gums. The membranes appear white or pale in contrast to the normal bright pink color. Bottle-jaw is swelling, or edema, in the lower jaw of a goat. Gastrointestinal parasite infestation causes a deficiency of proteins in the blood due to an increased demand for protein, and a decrease in the nutrient supply because of a lack of appetite (Ashraf and Nepote, 1990; Min et al., 2005). In heavy infestations and in young animals, a wasting away can be observed in which the animal has a low body conditioning score and a dull coat and appears unenergetic. Diarrhea may also develop as a consequence of infestation but the animal usually dies before it develops.

\section{Diagnosis of Goats for Parasite Infestation}

Diagnosis is usually performed by observing the clinical signs, performing a fecal egg count test, or using the FAMANCHA system to determine the level of infestation. The FAMANCHA system involves comparing the color of the mucous membrane of the eye against a FAMANCHA color chart in order to determine the extent of anemia, and the level of infestation by internal parasites (Luginbuhl, 2002; Waller, 2004; Gaskin, 2006). Training and certification in proper use of the FAMANCHA method is currently being employed in training workshops for producers, extension agents and educators at the Florida Agricultural and Mechanical University, Research, Extension and Teaching Center in Quincy, Florida.

Although this paper discussed tanniferous plants as a potential agent for controlling parasites in goats, other anthelmintic methods have been recommended. These methods include copper compounds, nutrition and neutraceuticals (Hale, 2006; Waller \& Thamsborg, 2004). In addition, the use of tanniferous plants in combination with other good farm practices may function to reduce parasites and the need for synthetic anthelmintics. Included in these processes are harrowing pasture rotation, selecting for worm resistant animals, manure removal, and "worm and move" programs. These programs will provide a strong defense against extensive parasite infestations and losses caused by gastrointestinal parasites.It is also important that more information and data is collected concerning the toxicity of the various tanniferous plants prior to planting in pastures.

\section{References}

Adejumo, J. O. and A. A. Ademosun. 1991. Utilization of leucena as supplement for growing dwarf sheep and goats in the humid zone of West Africa. Small Rumin. Res. 5:75-82.

Akhtar, M. S. and I. Ahmad. 1992. Comparative efficacy of Mallotus philippinensis fruit (Kamala) or Nilzan drug against gastrointestinal cestodes in Beetal goats. Small Rumin. Res. 8:121-128.

Ashraf, M. and K. H. Nepote. 1990. Prevalence of gastrointestinal nematodes, coccidian and lungworms in Maryland dairy goats. Small Rumin. Res. 3:291-298.

Bahuaud, D., C. Martinez-Ortiz De Montellano, S. Chauveau, F. Prevot, F. Torres-Acosta, I. Fouraste and H. Hoste. 2005. Effects of four tanniferous plant extracts on the in vitro exsheathment of third-stage larvae of parasitic nematodes. Parasitology. http://orgprints.org/6980/, Accessed 01-31-2008.

Bhatta, R., A. K. Shinde, D. L. Verma, S. K. Sankhyan and S. Vaithiyanathan. 2004. Effect of supplementation containing polyethylene glycol (PEG)-6000 on intake, rumen fermentation pattern and growth in kids fed foliage of Prosopis cineraria. Small Rumin. Res. 52:45-52.

Chandrawanthani, P., N. Yusoff, L. C. Wan, A. Ham and P. J. Waller. 2004. Total anthelmintic failure to control nematode parasites of small ruminants on government breeding farms in Sabah, East Malaysia. Vet. Res. Commun. 28:479-489.

Food and Agriculture Organization. 2003. Goat: population. Regional Office for Asia and the Pacific. Available at: http://www.fao.org/docrep/004/ad452e/ad452e2z.htm . Accessed May 2007. 
Gaskin, J. M. 2006. Mastering the McMasters method of fecal helminth egg count quantification. Presented at the Florida Goat Assoc. annu. conf., Gainesville, FL.

Hale, M. 2006. Managing Internal Parasites in Sheep and Goats. ATTRA. Retrieved January 19, 2007 from http://attra.ncat.org/attra-pub/PDF/parasitesheep.pdf

Hoste, H., L. Gaillard and Y. Le Frileux. 2005. Consequences of the regular distribution of sainfoin hay on gastrointestinal parasitism with nematodes and milk production in dairy goats. Small Rumin. Res. 59:265-271.

James, N. A., B. W. Berry. 1997. Use of chevon in the development of low-fat meat products. J. Anim. Sci. 75:571-577.

Ketzis, J. K., J. Vercruysse, B. E. Stromberg, M. Larsen, S. Athanasiadou, and J. G. M. Houdijk, 2006. Evaluation of efficacy expectations for novel and non-chemical helminth control strategies in ruminants. Veterinary Parasitology. 139:321-335.

Lange, K. C., D. D. Olcott, J. E. Miller, J. A. Mosjidis, T. H. Terrill, J. M. Burke, and M. T. Kearney. 2006. Effect of Sericea lespedeza (Lespedeza cuneata) fed as hay, on natural and experimental Haemonchus contortus infections in lambs. Veterinary Parasitology. Article in Press.

Luginbuhl, J. M. 2002. Gastrointestinal parasite management of meat goats. Available: http://www.cals.ncsu.edu/an_sci/extension/animal/ meatgoat/MGWormer.htm. Accessed May 4, 2006.

McMillin, K. W. and A. P. Brock. 2005. Production practices and processing for value-added goat meat. J. Anim. Sci. 83:E57-E68.

Min, B. R. and S. P. Hart. 2003. Tannins for suppression of internal parasites. J. Anim. Sci. 81:E102-E109.

Min, B. R., W. E. Pomroy, S. P. Hart, and T. Sahlu. 2004. The effect of short-term consumption of a forage containing condensed tannins on gastro-intestinal nematode parasite infections in grazing wether goats. Sma. Rumin. Res. 51:279-283.
Min, B. R., S. P. Hart, D. Miller, G. M. Tomita, E. Loetz and T. Sahlu. 2005. The effect of grazing forage containing condensed tannins on gastro-intestinal parasite infection and milk composition in Angora does. Veterinary Parasitology. 130:105-113.

Niezen, J. H., W. A. G. Charleston, J. Hodgson, A. D. Mackay and D. M. Leathwick. 1998. Controlling internal parasites in grazing ruminants with recourse to anthelmintics: Approaches, experiences, and prospects. International Journal of Parasitology. 26:983-992.

Nguyen, T. M., D. V. Binh and E. R. Orskov. 2005. Effect of foliages containing condensed tannins and on gastrointestinal parasites. Ani. Feed Sci. Technol. 121:77-87.

Paolini, V., F. De La Farge, F. Prevot, Ph. Dorchie and H. Hoste. 2005a. Effects of the repeated distribution of sainfoin hay on the resistance and the resilience of goats naturally infected with gastrointestinal nematodes. Veterinary Parasitology. 127:277-283.

Paolini, V., F. Prevot, Ph. Dorchies and H. Hoste. 2005b. Lack of effects of quebracho and sainfoin hay on incoming third-stage larvae of Haemonchus contortus in goats. Vet. J. 170:260-263.

Paolini, V., I. Fouraste and H. Hoste. 2004. In vitro effects of three woody plants and sainfoin extracts on 3rd-stage larvae and adult worms of three gastrointestinal nematodes. Parasitology. 129:69-77.

Scogings, P. F., L. E. Dziba and I. J. Gordon. 2004. Leaf chemistry of woody plants in relation to season, canopy retention and goat browsing in a semiarid subtropical savanna. Austral Ecology. 29:278-286.

Semenye, P. P. 1990. Toxicity response of goats fed on Leucena leucocephala forage only. Small Rumin. Res. 3:617-620.

Shaik, S.A. Terrill, T.H. Miller, J.E. Kouakou, B. Kannan, G. Kaplan, R.M., Burke, J.M. and Mosjidis, J.A. 2006. Sericea lespedeza hay as a natural deworming agent against gastrointestinal nematode 
infection in goats. Veterinary Parasitology.

139:150-157.

USDA National Agricultural Statistics Service.

2007. Sheep and Goats. Available at:

http://usda.mannlib.cornell.edu/usda/current/

SheeGoat/SheeGoat-02-01-2008.txt. Accessed May

2007.

Waller, P.J. 2004. Management and control of nematode parasites of small ruminants in the face of total anthelmintic failure. Tropical Biomedicine 21:7-13.

Waller, P. J. and S. M. Thramsborg. 2004.

Nematode control in green ruminant production

systems. Trends in Parasitology. 20 (10): 493-497. 